\title{
Review of Powell, Emilia (2020): Islamic Law and International Law: Peaceful Resolution of Disputes, Oxford and others, Oxford University Press
}

\author{
Alexander Niedermeier \\ Friedrich-Alexander-University Erlangen-Nuremberg, \\ Catholic University Eichstaett-Ingolstadt and \\ Deutscher Akademischer Austauschdienst (DAAD)
}

\begin{abstract}
Purpose - The purpose of this study is to critically review the book Islamic Law and International Law by Emilila Powell.

Design/methodology/approach - The book review is undertaken from a comparative legal and political science perspective, including arguments and insights from international relations, international law, Islamic law, Islamic culture, religious studies, legal history and European as well as international political history.

Findings - While the empirical part of Powell's work (chapters 5, 6 and 7) shows a methodologically veryc well done approach and at the same time highly interesting insights, both foundation and context show several critical points, in particular, a lack of differentiation with respect to the Western politico-legal tradition, its concepts and the resulting implications.

Research limitations/implications - The book represents an excellent starting point that should inspire new, more intensive as well as exhaustive research on this topic.

Practical implications - The book generates valuable insights for practitioners such as judges at international courts dealing with issues involving so-called Islamic law states, as well as politicians or public service officials in the context of international law and international politics.

Originality/value - As the paper is a comprehensive review of the book based upon comparatively based insights from international relations, international law, Islamic law, Islamic culture, religious studies, legal history and European as well as international political history, the arguments of Powell are analyzed and commented upon in a comprehensive, well-founded and fair way. This should give potential readers a good understanding of Powell's arguments, inspire a critical lecture of the book and contribute to the important discourse on the connex between international law and Islamic law.
\end{abstract}

Keywords International relations, Islamic law, Conflict resolution, International law, International Court of Justice

Paper type Literature review

(C) Alexander Niedermeier. Published in Review of Economics and Political Science. Published by Emerald Publishing Limited. This article is published under the Creative Commons Attribution (CC BY 4.0) licence. Anyone may reproduce, distribute, translate and create derivative works of this article (for both commercial and non-commercial purposes), subject to full attribution to the original publication and authors. The full terms of this licence maybe seen at http://creativecommons.org/ licences/by/4.0/legalcode

Islamic Law and International Law 
REPS

5,4
Review Essay

Powell Emilia Justyna (2020): Islamic Law and International Law: Peaceful Resolution of Disputes, Oxford and others, Oxford University Press.

All too often Islam is perceived and portrayed as incompatible with Western concepts of social, economic, political and in particular legal thought. Islam frequently is equalized with Islamism, and Islamic legal thought presented as "the" Sharī'ah, which is regarded as nothing more than the embodiment of the polar opposite of Western rationality, humanity and human rights, liberalism, pluralism, enlightenment or civilization as a whole. Regularly, both Islam and the West along with their respective attributes are presented as monolithic phenomena. This problem is also put forward by Emilia Justyna Powell as one of the reasons to write her book Islamic Law and International Law: Peaceful Resolution of Disputes.

Rather at the beginning of her work, she articulates a reproach Western scholarship that there was a lack of recognizing the variance within the Islamic milieu. Rather, all Islamic law states (ILS), a term which will get more explanation further down, are seen as simply Islamic and "Islamic in the same way, to the same degree" (3). Translated to the international legal realm, this according to Powell, leads to an assumption of a clear and universal dichotomy between Islamic law and international law throughout the entire Islamic world (3). Those who know the intercultural practice either within or beyond the academic world in the fields of law, security, international relations and beyond, are aware of the complexities that find no sensible representation in these depictions. Though they prevail and, in many instances, it is particular in the international realm where the complexities of Western and non-Western concepts meet and interact that prejudices especially against a fruitful, harmonious and constructive conversation between international law and Islamic law can be found. This is even more regrettable for a number of reasons, namely that international relations have become more intercultural, that the Islamic world (however defined) has increased its role in international relations, that the international system is becoming more diverse and multipolar, and since also regional conflict become of global salience. Finally, Islamic law constitutes a real influential factor in domestic as international political decision-making. Given this background, questions such as how ILS "view international law and international peaceful resolution venues" (2) become of prime importance. It must not and no more be ignored, if for example, international courts and conflict resolution mechanisms are systematically ignored for reasons lying within Islam and whether there is or is not an incompatibility of Islamic law and international law. Therefore, a book like the one by Emilia Justyna Powell, which she recently presented to the (academic) world and that the author herself classifies as the first book in English language to cover this issue, comes at the right time.

In her book, Powell is attempting nothing less than finding an answer to the "Shariainternational law nexus puzzle" (8). What she is interested in more concretely, is finding an answer to the question of how the relationship between Islamic law and international law, each of which is regarded by Powell as a distinct normative framework - can be framed, understood and defined particularly when it comes to peaceful conflict resolution. In this vein, she wants to understand whether the tension between Islamic law and international law can be mitigated or whether it would rather be necessary to steer away ILS from the influence of Islamic law toward a stronger or even exclusive role of international law. For this purpose, Powell's attempts to develop a generalizable mid-range theory (16 f.), which shall serve as explanatory instrument for ILS' view of all conflict management venues. The decisive factor to explain international variation is the domestic legal system. More precisely, she wants to find out, whether the specific balance between secular law and 
Islamic law in the domestic realm of a particular ILS does influence the country's preference with respect to peaceful dispute settlement (10). The implicit hypothesis in this connection goes: the higher the Shari' ah influence within the domestic legal system of an ILS, the more likely is it that this ILS will firmly adhere to Sharī'ah-style elements of international dispute settlement, i.e. international non-binding third party dispute-settlement mechanism such as mediation and conciliation which are procedurally similar to Sharīah-based conflict resolution (12).

In this context, questions such as what factors influence the reliance of ILS on peaceful dispute settlement provided by international law institutions such as the International Court of Justice (ICJ) and what the preference of other states for rather informal mechanisms/nonbinding third-party methods such as mediation and conciliation are raised (10). In this vein, the book has the intention to raise awareness of non-Western and in particular Islamic legal thinking and modes of law and justice and it further wants to make clear that in different countries, different understandings of what law actually is and how it shall be understood and executed, exist. In addressing primarily academic scholars as well as practitioners of international law, judges of international courts and representatives of non-governmental organizations promoting peaceful conflict management, Powell's hope is that "international law's authority can expand" (6), should these domestic understandings and practices once be integrated on the international level.

By now it should have become obvious that the book was (purposefully) neither designed as a textbook nor as a historic work, but rather as a piece of original research. This aspect is worth mentioning to avoid any wrong expectation as to, for example, a systematic analysis of international and Islamic law from a comparative perspective, which Powell by intention does not want to provide. Thus, when Powell deals with international law and Islamic law in chapter 2 , it is only in a cursory and selective manner, which, as we will see below, is not without difficulties. But she uses this particular approach to these normative systems primarily to develop the category of ILS, which she explicitly presents as a unique category in the field (85). With this categorization, she challenges the reader who might be looking for all too easy explanations of a complex construct. Thankfully, Powell accepts the reality of diversity and complexity of the subject as a prerequisite for getting a chance to understand the implications of the very diversity and complexity of Islamic law within the domestic context on the behavior and in particular its variation on the level of international legal institutions. By drafting the category of ILS, Powell rightfully states that there were necessarily "grey areas at the edges of ILS" (49) admitting that a certain degree of subjectivity and arbitrariness was accepted on her behalf.

One could discuss if a more rigid process of determining her core concepts might have benefited her project, but taking the ILS concept at face value seems to serve her purpose well and obviously both arbitrariness and subjectivity are kept in acceptable limits with convincing explanations being provided. Powell straightforwardly states that the attempt to give a definition of what an ILS is was primarily owed to the empirical reasons that were to enable a systematic analysis of state behavior at the level of international institutions, not so much as to add to the debate from a more civilizational point of view (43). For this purpose, the main focus is also set on the legal system and tradition. The concept of ILS thus concretely comprises "states where the overwhelming majority of the legal system is charged with obligatory implementation of sharia, as well as states that limit the direct, obligatory influence of sharia to a part of their official laws, such as personal law or criminal law" (50). This, however, also means that at the heart of the ILS category, we can find "unity in diversity" (50). Designed as just described, Powell's concept of ILS purposefully is distinct
Islamic Law and International Law 
REPS

5,4

338

from alternative concepts such as Islamic states, Muslim states or Arab states, in which the author sees a distinct notion of "Islam-ness" (44) she wants to overcome.

At the same time, she rightfully criticizes the lack of concreteness in the existing concepts as far as an exact definition is concerned. For example, Powell shows that the focus in the concept "Muslim state" is more on the population than on Sharī'ah aspects. The problem of this definition becomes salient in the case of Turkey, where despite its vast Muslim majority, the state cannot be understood as an ILS (44). The same problem in principle applies to the existing category "Islamic state" where it regularly remained unclear what exactly made the state Islamic: religiosity of population or institutions, to name just a few options. The category "Arab states" on the other hand excluded important non-Arab states where Shari' ah had trickled into the constitution and/or laws of lower status. The category "Middle East" merely referred to a geographical dimension that in addition was highly disputed. Certainly and despite this fact, Powell could and possibly should have made clear more explicitly where she refers to ideas from existing concepts. But to a certain degree, this issue is negligible as the ILS category in her study is rather a means than an end. And indeed does Powell convincingly argue that none of the exiting definitions turned out to be suitable for her endeavor in which she aims at analyzing the situation in a world where she sees two normative frameworks, namely, international law and Islamic law, simultaneously at work. In this context, the ILS category is a "spectrum" (52) with each ILS being different with respect to its domestic legal realm. This concerns, for example, the constitutional reach of Islamic law ranging from most liberal and diverse in Malaysia and Indonesia to the most strict constitutional reference to Sharī'ah as well as the highest degree of coherency as to the notion of the one understanding of Islamic law as part of the domestic legal system in Saudi Arabia and Iran (52 ff.). What is decisive here is that considerable disagreement with respect to the right balance of religious and secular law within ILS can be observed (59). And this basically is the starting point for Powell's analysis of if and how domestic differences in the legal system as to the interplay of Shari'ah and non-Islamic elements translate to preferences when it comes to the choice of conflict settlement mechanisms in the international realm.

The fact that the book is meant as a piece of original research is also reflected in the overall structure: chapter 3 lays further groundwork for Powell's theoretical argument when she juxtaposes the Islamic legal tradition and international law by showing differences and similarities between the two systems referring both to historic processes and academic conversations. In chapter 4, Powell develops her theoretical argument of how and why a domestic legal international relations (IR) system reflects the way that a society regulates and grapples with dispute resolution (21). Chapters 5-7 are the location of empirical analysis, with chapter 5 providing an analysis of ILS' decisions to use specific mechanisms for conflict management in the context of territorial disputes, chapter 6 examining the relations of the ICJ, the main judicial organ of the UN-system, to the Islamic milieu, and chapter 7 is as extension of the analyses in the previous chapters involving the arguments of various schools of Islamic jurisprudence as well as taking into consideration geographical aspects. From a methodological perspective, Powell chose an interdisciplinary oriented mixed-methods approach with the quantitative element comprising the quantification of domestic Islamic law with the attempt of coding 172 constitutions and major constitutional amendments, and the qualitative element entailing in-depth qualitative interviews with Islamic law scholars and practitioners. A (purposeful) particularity is the fact that Powell leaves away any direct source of Islam. The book's conclusion finally provides the insight that there are more similarities between international law and Islamic law than often accounted for in the realms of policy and academia. 
It is clear by now, what purpose and general message Islamic Law and International Law: Peaceful Resolution of Disputes has, and so are its addressees. What is yet unclear is where to localize the book discipline-wise? Powell's research explicitly is meant to be a contribution to the study of international law of peaceful resolution of international disputes. Inspired by existing misinterpretations of Islamic law by the international community, the author wants to inquire how international law is perceived through the lens of the Islamic legal tradition. Spanning the confinements of disciplines, the author herself struggles somewhat with the categorization of her work: she states that it did not fit squarely into the Islamic studies Islamic Law and International Law literature and rather might be seen as a contribution also to political science and in particular international relations. At the same time, her book should be understood as a contribution to the growing work which is part of the so-called empirical turn in international legal scholarship (17). In this situation, the reader might long for a somewhat clearer statement concerning what the author actually is really focusing on. At least it is somewhat hard to discern as in her introduction, research aims, purposes and rationales do not always appear crystal clear. Her book shall be a contribution to international law and not so much to Islamic law, but somehow still to Islamic law, a contribution to international law and to international relations, but somehow less so to IR. It also shall in some way contribute to comparative law and constitutional law; however, not primarily. So what shall the prime message to the reader be?

For certain, it is unavoidable that a research project as the one provided by the author is a complex endeavor, and thus automatically touches areas such as comparative law, constitutional law, interests and traditions - legal and otherwise such as socio-cultural ones for example. But does this really mean that the book will generate sufficient new insights in each and any of the fields, disciplines, sub-fields and sub-disciplines touched and mentioned? Less information sometimes is more and more structure particularly in the introduction would have caused less confusion to easily grasp what the author is up to. Reading through the introduction, the reader might easily get the impression that a whole number of extra goals (of quite remarkable significance at times) are mentioned that shall be attained in a manner of swiftly passing by. Doubtlessly (and unfortunately) promoting a research project nowadays requires every project virtually to be presented as a game changer for the field providing the whole society with unprecedented benefits, but an introduction to a book should not resemble a research grant application, which it does in this case at some occasions. The author would have been well advised to present her as such excellent research idea in a somewhat more modest manner a more focused way.

But her introduction involuntarily also reveals another dilemma of current research: the complex reality of today's international relations (including international law) and its consequences for each scholarly endeavor dealing with it. Somehow addressing this complexity would require the model type of renaissance human being deeply knowledgeable in all disciplines, which in our case means that the author would need to be an expert at least in political science, international relations, law (and not only international law and Islamic law but also in comparative law including a whole variety of legal systems and traditions around the world), religious studies (including Islam and Christianity, but way beyond), to name just a few, not to mention anthropology, cultural studies, sociology, social psychology etc. Today's knowledge is too vast for any single human being to cope with. Thus, quite unavoidably, also this book, despite its extremely valuable insights assumedly nobody wants to miss, comes with a number of short-comings. Both, the valuable insights and the problematic passages shall be discussed in the following paragraphs.

It has already been mentioned that Powell's work is not designed as a textbook and that this fact leads to a cursory and selective reference to the field of Islamic law. With the same 
REPS

5,4

argument, Powell states that she refrains from any explicit definitions and discussion of contentious issues or concepts such as Sharīah, Islam, Islamic law, or secularism. She explicitly states that she is "leaving to other scholars the arduous task of providing or questioning definitions" (18). But how acceptable is this excuse? Is it legitimate to avoid dealing with core concepts from a definitional and critical point of view, instead of at least briefly showing and taking position to the relevant core concepts and discussions, at least as far as they touch upon the main arguments of the author herself? Particularly, as she argues that her topic, the interaction between Islamic law and international law, is full of misunderstandings, her way appears too evasive. Even if neither textbook nor history book, a brief systematic discussion of central concepts instead of a mere, cursory and therefore at least seemingly arbitrary choice of elements from the respective systems and their historical and social contexts would have been required for the book - not only to provide the reader with sound and differentiated knowledge, but also to shield the author against the reproach of too high a degree of arbitrariness and possible bias in her selection.

Another, more serious issue is the creation of the dichotomy "Islam" vs "West." The problematique in this context lies less in the contrasting itself but rather the different ways of dealing with "Islam" on the one hand and the "West" on the other. While Powell stresses her aim of introducing the notion of variance into the Islamic milieu to rectify and overcome the binary construction of Islamic Law as Islamic or non-Islamic (4), the "West" is portrayed as rather monolithic. Writing about Islam, she rightfully argues that the individual specific combination of Islamic and secular elements in the legal system of each individual ILS needed to be taken into consideration as this particular combination had a significant specific impact on the way international conflict management was perceived by the respective ILS. Talking about the "West," no such differentiation can be observed. It is even stated that most of the West Europeans "think, see, feel, and act according to Christian civilization, which originates in the pre-modern period" (99). There is a clear lack of differentiation and of showing the ethnic and religious pluralist realities of Western European societies in particular and Western societies in general. She rightfully alludes on several occasions to the dynamism inherent in societies and legal systems, but here she does not account for it. Allusions to the recent and current changes and challenges to the traditions by immigration, which has been going on for decades and that also has already affected ways to think and act in the political, economic, social and legal realms in Western countries from the Islamic world for example and their implications also on the topic of her analysis in this book unfortunately are missing. Western legal systems and Western culture appear as monolithically closed and undynamic in her description.

Furthermore, it is argued that the West was characterized by an overwhelmingly litigious culture (89). In this context, Powell neither explains what she understands under the culture of the West, i.e. neither the "the" nor the notion of (seemingly monolithic) "culture" are further discussed, nor does the reader get an explanation of why the entire culture of the West is characterized as "overwhelmingly litigious" (87). While it is doubtlessly important to create a deeper understanding of Islamic law (including variance and developments) to enable/improve intercultural dialogue (5), the same is required with respect to the West. Western legal systems do by far not all look like the British or American model and neither are their legal cultures identical. However, this impression arises on various occasions in the book. The self-imposed claim to add to the knowledge in comparative law, which inherently requires a deeper-going understanding of this very field of comparative law and along with this an in-depth knowledge of a significant variety of different legal systems and cultures, cannot be fulfilled this way and also might lead by some reader to questioning the expertise of the author in this field. 
This problem also affects the empirical studies, for example, with respect to the holy oath as one factor in the operationalization of the Islamic-variable concerning the domestic legal system of ILS. In her dichotomic contrasting of Islamic law and Western law, Powell underlines the role of holy oaths as defining element of ILS, at least suggesting that this feature is opposed to the politico-legal realities in Western law countries. Powell argues that holy oaths defined as oaths to God "constitute an important element of the Islamic legal tradition" (65). She shows not only that "[s]tate officials of some ILS are constitutionally required to take religious oaths before assuming office" (65), but also that "[j]udges, especially at the highest levels, may be constitutionally required to take holy oaths" (66). Notwithstanding the possible implication of Powell's assumption that holy oaths do not play any role in Western law and politics, a closer investigation reveals that not only do many constitutions of Western law countries show explicit references to God, but also that holy oaths are by far nothing unusual for state representatives or judges in Western politico-legal realms. Looking merely in the state constitutions of the German länder (the federal states of Germany), it becomes evident that 7 out of 16 of these constitutions explicitly refer to God. Article 12 of the State Constitution of Baden-Wuerttemberg for example clearly states that the state's youth has to be educated in awe of God and in the spirit of Christian benevolence. In the very same constitution, we find regulations concerning holy oaths for civil servants. Regulations concerning holy oaths can also be found for example in the German constitution (Art. 56, 64 GG) as well as in the German Law on Judges (§38 DRiG). Explicit references to God can also be found inter alia in the national constitutions of Greece, Ireland, Poland, Switzerland, Russia, Argentina, Brazil, Paraguay, Peru, the Philippines and Canada as well as those of sub-national units.

These references are far from trivial. The state constitution of Rhineland-Palatinate for example states the "awareness of the responsibility for God, who is the primal ground of law and the creator of all human society," while the Swiss constitution shows the words "in the name of God the Almighty." Particularly clear is the wording that can be found in the constitution of the Republic of Ireland: "In the name of the most holy trinity, from which all authority is derived, and to which as our final aim, all action of individuals as well as states, must be directed, we, the people of Ireland, acknowledge, in humbleness, all our obligations to our divine God, Jesus Christ.” Article 6 of the same constitution even states that power and sovereignty comes from God and the people. It needs to be acknowledged that there is a discourse concerning the deeper meaning of a reference to God in constitutions.

Sometimes it is argued that this reference is meant as counter-point to totalitarian forms of statehood and directed against the notion of the state as the supreme authority. While some argue that the people act as the sovereign, other argue that these still represent the state as earthy manifestation of the supreme authority from beyond, i.e. God. Even if often argued that no explicit faith is or should be addressed, a significant number of Western state constitutions undisputedly refer to Christian faith. The great meaning of the reference to God is also confirmed by the fact that critical arguments against its existence can be observed in many discourses where it is argued that the constitutional reference to God represents a contradiction to state neutrality in matters of belief and a breach of the separation of state and church doctrine. The fact alone that this discussion is part of an ongoing discourse clearly shows that also the separation of church and state that is depicted by Powell as a crucial feature of Western politico-legal systems is not as unambiguous as presented by her. The reality shows a much less strict separation of state institutions and religious ideas, for example, in the form of symbols, than claimed or demanded. When Powell therefore argues that the separation of church and state "proscribes the explicit 
REPS

5,4

342

usage of religious sources or religious argumentation in the court room" (107), cannot be left entirely undisputed.

This also applies in this context to her argument that the Islamic legal tradition was more diverse than other legal traditions because the balance between religious laws and secular laws within ILS were subject to frequent renegotiation (50). While a discussion between religious and secular arguments may be more intense in ILS than in Western ones, it is far from reality that in Western politico-legal systems discourses of these types were rare, unimportant or without sometimes significant impact. Issues brought to Western constitutional courts such as the obligatory Christian school prayer, the obligatory display of crosses as Christian symbols in class rooms of public schools or the discriminant way of dealing with the display of the symbols of different faiths by public officials while carrying out their duties, which were also fought fiercely by referring to religious arguments, show that also Western law states observe processes of negotiation and renegotiation of religious components in legal matters. Admittedly, this is not exactly Sharī'ah law vs secular law, but mentioning the existence and the impact of this kind of discourses in Western law states would have provided a more complete picture.

In this context, another problem of Powell's approach becomes evident. While she provides examples and explanations to show the uniqueness of as well as the diversity within the Islamic tradition, she does not do the same for the Western culture or other non-Islamic traditions. This, however, means nothing else than that her arguments with respect to Islam are well argued and justified while the ones concerning the West and non-Islamic traditions need to be bought by the reader as they are presented by Powell. When she claims for example that ILS are "different from other countries where Christianity, Buddhism, or Hinduism plays an important societal role" (63), no explanation follows why this is claimed to be the case and what exactly the other traditions mentioned look like in comparison. The problem gets even aggravated by the way Powell, with good reason, qualifies the rigidity of ILS' constitutions. She tells the reader that she "recognize[s] that Islamic ideals are practiced differently across the ILS category" (81), an observation she even sees at the core of her book (81), and also that she "recognize[s] that in some of the ILS there is a real difference between the dogma of Islamic law and actual state practice" (81).

But how can she speak in favor of Islam's special role as compared to the West and other traditions by focusing on the role of religion and not allow the same line of argument be applicable when it comes to non-Islamic traditions? It would have been necessary to deal at least with Western constitutions in the same depth and width as with the constitutions of ILS if a real validity of the study should have been attained. While it is striking, as Powell demonstrates that in a number of ILS high state officials need to be Muslims, it should be clearly shown whether rules like these are definitely non-existent in other traditions, be it Hinduism, Buddhism, Christianity, Jewdom or any other religion of practical relevance. The same applies to the formal mentioning of specific religious texts or overall principle as the leading guideline for law-making and jurisdiction. In this context, the question arises: What does it really mean when the constitution speaks of the supremacy of the Shari'ah in the practical application of law beyond mere rhetoric in various ILS? How solid is the argument of difference when Powell states that "the respect for state sovereignty and national interest may challenge and at time trump considerations for Islamic norms" (82) and at a different place provides arguments such as that all countries including ILS "are guided by their material preferences" (82) and "sharia constitutes only one of the manifold forces" (82) that determine how government operates. Does this not eventually lead to one specific question: Are constitutional claims and political reality in the real existing ILS and Western law states 
really that different? The answer could be yes, but then it would need to be much better founded.

In this context, another critical issue arises. Islamic law is presented as being religious, while international law is portrayed as being secular. One foundation for this argument can be found according to Powell in the significant differences in the historic development of the two legal systems. While Islamic law could not draw on an existing legal system, but rather merely on tribal custom, Christian law could draw from Roman law as a secular legal system already in place $(94,100)$. This information is important as Powell also shows that many principles of international law have their roots in ancient Rome, Greece and medieval Europe (94). And they are, as Powell argues, responsible for the different paths the two legal systems in question took. While in the context of the Islamic legal system Powell sees the simultaneous development of legal and religious precepts $(94,100)$ with the creation of legal and religious provisions often conjoined (100), she argues that the sources of international law were informed by Christian ideas but they yet were in principle secular (102).

This dichotomy, even if it alludes to the correct trend, however, cannot be left unspoken to as it is not as sharp as suggested here. First of all, Roman law was not an entirely secular legal system. Rather, the ancient Roman jurisprudence was based on unstructured legal and sacred law. The legal statement was incumbent on the king and a college of priests who advised the high priest in his competent authority. The archaic sacral law system with its statutes, regulations and rights and criminal offenses, such as the crimen incesti, remained in the jurisdiction of the priestly college (fetial college) under the pontifex maximus. But the religious aspects can also be seen in legal provisions that may be regarded as predecessors of international law. The Roman Empire, for example, legitimized its war campaigns by opening them with cultic rites by the fetial college. A priest informed the neighbor to be conquered by the exact Roman demands and was to declare war after a certain deadline had passed. The assumption was that the subsequent war was authorized by the Gods and thus just. The religious component also becomes evident in the interpretation of wars: defeats were interpreted as a sign by the Gods that the war was not authorized as just by them while victories were seen as divine legitimization of wars - even ex post.

Beyond the argumentative reference to the Roman legal culture, Powell also refers to the Christian sources of international law. While she argues that it could not be denied that international law, as it emerged and developed in the West, had deep roots in Christian faith, it, at the same time, however, needed to be underlined that the Christian influence had been less direct; Christian religion rather "served merely as a foundation or an inspiration for specific rules" (95). It is certainly true that, as Powell writes, "the Bible was not considered a direct and exclusive source of international law" (99), and it rather "was referred to alongside secular rules, or used as a normative support for positive rules" (99). Nevertheless, it seems at least questionable to argue that Christianity for throughout the entire time that international law has been developing in the West has only been inspirational and that the influence of European civilization was basically secular as suggested by Powell (100).

While she states Grotius as proof for this development, she leaves aside virtually the entire middle ages which may doubtlessly also be regarded as one of the formative periods of international law, as she herself argues. The respective contributions of Augustine and Thomas Aquinas in particular should have been mentioned to get a fuller and more differentiated picture of international law. Augustine for example defined peace as goal of world history which, however, can only be attained by God. To attain this goal at least approximately on earth, which is striving for peace, the church as the institution representing God is required. The task of the church in this context was to remind the state 
REPS

5,4

authorities of their duty to create and to protect and maintain orderly peace and harmony (ordinate concordia) between the believers and unbelievers.

By integrating traditional Roman state ethics into Christian eschatology, St Augustine transfers Christian thought directly into practical (international) policy. This motif becomes particularly salient in his justification of war. In his work Contra Faustum Manichaeum from $397 \mathrm{AD}$, he argues by reference to Moses' Biblical wars, which were not waged for a lust to conquer but by the order of God as revenge for previous war against the people of God and as deterrence against future threats, that a war that is ordered by and in the name of God must not be disputed as it will not damage neither God nor his saints. Just war thus was to be interpreted as a test for the patience of the believers. Particularly wars against the enemies of Christianity within and beyond the Christian faith were counted among this concept. Following this line of argument, for example, Pope Gregor the Great (590-604) legitimized both violent action against heretics and wars against non-Christians. Also, the different use of cruel weapons such as crossbows against Christians (not allowed) and Muslims (allowed) was legitimized on the second Lateran Council in 1139. Even the Bible itself was referred to in questions of international law, for example in the case of the Decretum Gratiani. Through canonized church law, the political role of the popes was increased and thus the impact of both the church and Christian politico-legal thought on the understanding and practical conduct of international affairs.

Building on Augustine, Thomas Aquinas systematized the politico-legal ideas of state and war. One of his main ideas was the protection of believers and non-believers which led to his concept of peaceful co-existence of these two groups with the argument of religious salvation for all. In this vein, war was regarded as a way to preserve peace and thus the road to salvation for everyone. In other words, the protection of peace was equalized with the protection of the Christian religion, which was regarded as the only and universal way to heavens. It shall not be left unmentioned that Powell does at one point mention that "the process of international lawmaking, being deeply influenced by canon law, was believed to be inspired by God and thus there was limited, if any, need to search for rational justification for norms and rules" (95). But that is virtually all she wants to reveal on this important matter. And it is immediately qualified when she writes that "[h]owever, [...] there was an emphasis on reason and logic, on intellectual doctrine as the basis of international law" (95).

When Powell writes that Grotius opened the way to "reason, logic, and secular rational calculations and philosophies" as "benchmark for the establishment and interpretation of international law" (97), she certainly is right. But the development of international law is by far not an endeavor of merely secular Roman law enriched with some Christian ideas and Grotius' international legal thought inspired by reformation and early ideas of the looming age of enlightenment. Neither is there a direct line between the primarily secular influences on international law between Rome and Grotius, nor must it be forgotten that the transformation from primarily religious to primarily secular-rational arguments in international law also started out of a first and foremost Christian/Catholic religious context. Way before Grotius, this process started with religious legal thinkers such as Francisco de Vittoria in the early 16th century, who was a Catholic moral theologist, scholar of natural law and founder of the Spanish late scholastic and its institutionalization, the School of Salamanca. His achievement was the development of answers for the new challenges of a peaceful international order between the early modern states on the one hand and the relationship between the Europeans and their colonies on the other hand, from the ideas of a differentiated scholastic tradition of the Middle Ages. A crucial element of change was his reference to both theological and rational philosophical arguments. On the grounds of his international legal thought, the Roman concept of jus gentium as law of how Rome was 
dealing with subordinate strangers was further developed into a jus inter gentes of - at least in theory - peoples of equal legal standing. This again is compatible with Powells' quoting of Vattel whose focus point was the "quality of men," not the "character of Christians or Mohammedans" (97). The further developments briefly described in Powell's book are undisputed, such as the development of specific type of dispute settlement with the Peace of Westphalia (1648), the Jay Treaty (1794) and the Hague Conferences of 1899 and 1907 as important milestones.

But in this context, too, the reader will be confronted with too strong a dichotomy

Islamic Law and International Law between Western and Islamic concepts. Powell states, for example, with reference to exclusivity in Islamic law that "ownership of all things is vested in God" (176) with the consequence that "any individual owner has, to an extent, a responsibility to share with the community" (176). The differences to the Western concepts, however, are not as striking as suggested - neither on the theoretical nor on the practical level. In practice, the second statement reveals that individual property is real also in ILS, independent from the notion of ultimate ownership being vested in God. The visibility and practice of this notion, as the author argues, can be found in the responsibility of the owning individual to share with the community. But the idea that property compels is not an idea that is alien to Western politico-legal thought. The social obligation of property (also social commitment of property) describes in the German context, to provide just one example, a legal and socio-philosophical principle. In the constitutional sense, the social bond restricts the area of the protection of property according to Article 14 paragraph 1 of the German constitution.

The important thing here is that this notion stems to a significant degree from Christian social teachings. In the encyclical Rerum Novarum (1891), Pope Leo XIII quotes Thomas Aquinas: "Man must not regard and treat external things as property, but as common good, in so far as he should understand easily when sharing them to those in need. That is why the apostle says: 'Command the rich of this world [...] that they gladly give and share." In Quadragesimo Anno (1931), Pope Pius XI emphasizes that the income from the interaction of labor and capital must be made available to the general benefit. In the Pastoral Constitution Gaudium et Spes (1965, no. 69) of the Second Vatican Council, the principle is formulated as follows: "God designed the earth and all that it contains for the benefit of all people and peoples; therefore these created goods must be of the benefit of all in a reasonable proportion; justice has the lead, and love goes hand in hand with it. [...] It is always important to pay attention to this general destination of goods. That is why the person who avails himself of these goods should not only regard the external things that he rightfully owns as his own personally, but must at the same time also regard them as common goods in the sense that they are not only for him but also for others can be useful." These ideas have also influenced a variety of Western constitutions other than the German.

Also, the notions of territoriality and sovereignty as provided by Powell deserve closer critical attention. In her analysis, Powell inter alia presents the example of the conflict between Morocco and Mauritania concerning the Western Sahara issue as an example for the incongruity of Islamic and Western interpretations of the principle of sovereignty with respect to territoriality (178). Both Morocco and Mauritania justified their claims to Western Sahara by referring to personal ties of allegiance between Saharan nomads and state-like entities in what is now Moroccan and Mauritanian territory (178). But is this type of thought completely alien to Western history and thought? Definitely not. Again, the disadvantage of ignoring crucial eras of Western politico-legal history in general and Western European politico-legal history in particular takes its toll here. For many of its historically decisive centuries, Europe was characterized by splintered territoriality and splintered sovereignty. Basically, all functions characteristic for the modern state were distributed over a whole 
REPS

5,4

variety of actors. Not even the corporate state showed true political unity. Because of the distributed competences, on the very same territory there was a side-by-side of the authorities of several rulers. The respective power units only were loosely tied to each other. Society rather was organized by chains of personal dependencies which was reflected also in the role of the emperor of the Holy Roman Empire of German Nations who did not dispose of own armed forces and was himself dependent on vassal services. With a frequent recourse to the fiefdom pyramid, the emperor was suzerain rather than sovereign within this composed system of society and governance.

It is worth mentioning this aspect for two reasons: first, to show that the Western understanding of statehood and governance has never been just based on the outcomes of 1648 (and predecessor events such as the Augsburg peace of 1555), which indeed paved the way for a specific and today actually dominating understanding of sovereignty and territoriality in mainstream IR and international law. And second, because this very notion of the Westphalian system currently is challenged, not only by understandings as rightfully portrayed by Powell and also by so called Eastphalian visions of statehood and world order, but additionally within the West itself. The European integration project is increasingly challenging and possibly re-dissolving the fixed congruence of territoriality and sovereignty that as a matter of fact has determined Western understanding for roughly the last three to four centuries. All these insights are not running counter the general idea of Powell's argument that Western and Islamic politico-legal traditions have a significant number of contact points that are well suitable to bridge the existing gaps. The opposite is true, and telling a more comprehensive and differentiate story would have added significantly to the quality of the project and would have even supported it.

There are two issues that puzzle the reader in the context of the case of Morocco vs Mauritania concerning West Sahara. Both refer to the Islamic understanding of sovereignty and territoriality as it is presented by Powell. In the dispute, Algeria's Advocate Mohammed Bedjaoui proposed that the ICJ should consider the concept of dar al-islam. The ICJ, however, did not take up this recommendation and, as Powell writes, "adhered to the territory-based, Western notion of sovereignty by stating that allegiance to a ruler, if it is to be associated with sovereignty, "must clearly be real and manifested in acts evidencing acceptance of his political authority." But why should this be a contradiction to the Islamic understanding? The Nomad population could adhere to the Moroccan king rather than the rulers of Mauritania if they really felt allegiance to the former independent from their location, at least in theory. The ICJ could also mean this rather than alluding to the territorysovereignty-connex. At least as the case is presented here. The separate opinion of the Spanish Judge Frederico De Castro who as a matter of fact outrightly criticized Morocco for "failing to base its claims within the Western concept of sovereignty" is not enough to prove the interpretation of the judgment presented here. I do not argue that it is true, but simply say that the information provided is not sufficient.

The same applies with respect to the dar al-islam-argument put forward by the Algerian advocate. As traditionally, dar al-islam is defined as the territory under Muslim rule as opposite to dar al-harb, it would have been interesting to learn more about the dar al-islamargument in this very case as also Mauritania is an Islamic Republic. So why exactly should a decision favor Morocco? In particular, would it have been essential for the reader to learn who called for the ICJ with what arguments. Also, a more deep-going interpretation and discussion by the author of the role of the territoriality and sovereignty argument on either side beyond the mere arguments provided by the conflict parties would have been enlightening. This analogously applies in principle to the case of Indonesia v Malaysia over Pulau Litigan and Palau Sipadan (178). 
Another case where a further contextualization as well as a more deep-reaching discussion would have been required is the Libya $\mathrm{v}$ Chad dispute before the ICJ. It would have been particularly interesting to learn more than one mere statement that the ICJ did not accept Libya's argument of personal loyalty to the Caliph in the conflict between Libya and Chad (178). What was the exact argument involving the Caliph (which Caliph, by the way) and how could the ICJ have taken up that sort of argument referencing to international law? Unfortunately, the information provided in these cases is too scarce to make up one's own mind and thus important questions remain unanswered. With the reader unable to get the big (or at least a significantly bigger) picture, these examples lose a lot of their illustrative power for the author's argument.

Until now, my critique was primarily touching upon the dealings of the author with the Western legal tradition and its impact on international law. Powell, however, does also address the relationship between the Islamic legal tradition and international law. Unfortunately, however, this as such highly welcome and extremely important issue appears not as crystal clear and unambiguous as it would be preferable by the reader. At one point, Powell clearly states that "International law has been shaped by Western legal doctrine" (89). I mention only en passant at this point that again a clear conceptualization of what the Western legal doctrine should mean exactly is missing. And so is any mentioning of the degree to which it had been shaped. But apart from these issues, it does neither entirely become evident whether international law and Islamic law shall be presented as standing in stark opposition to each other, nor what the exact influences of Islamic thought and their specific impact on international law actually were.

What is first of all excellent and very important in this context is that siyar as the Islamic international legal thought is presented in some detail - unfortunately often widely unknown beyond ILS - as Powell rightfully states "the Islamic milieu has contributed many scholarly treaties on international law" (89). What unfortunately does not come out, however, is to which degree Islamic law has impacted and/or interacted with the currently prevailing so-called Western international law, or put in other words if, when, how and to what extent Islamic notions of international law have influenced mainstream international law. Powell does underline that it would be "essential to be familiar with the influences stemming from Islam" (89) and that Shar'̄'ah introduced a different set of religious standards to international law (103). But the reader at no point learns what these influences and sets of religious standards were. It is true that Powell says that siyar, while being "partially planted in spirituality and divine authority" (40) and adding the "weight of religious sanction" into international legal thought, it covered substantive issues with relevance to international relations such as treaty obligations, maritime exploration or diplomatic protection (40). But she provides no more information. At the same time, she lets the reader know that there was no coherent body of siyar (40). Unfortunately, Powell discusses neither the implications of the existing concepts of siyar which she mentions nor of the limitations arising from the lacking coherent body of siyar. Also, with respect to the concrete relationship between Islam, Islamic legal thought and (Western) mainstream international law, neither the actual character of this relationship nor the arising implications are clearly stated. The reader learns that siyar, according to Powell, can be understood analogous to jus gentium in Roman law, regulating relations of Roman citizens and non-Romans and relations between non-Romans (40).

Thus, siyar is directed at regulating the relations between Muslims and non-Muslims and relations between non-Muslims. But what does this mean exactly? And what does this mean for ILS and non-ILS when she writes in this context that "Islamic international law is specifically addressed to Muslim collectivities and reveals Islam's struggles to construct a 
REPS

5,4

348

justly ordered community of states" (152)? This question becomes even more important when the issue of war is concerned. Powell presents state conduct during war as "[o]ne of the first developments in international law" (88) where she not only notes by quoting Awn Shawkat Al-Khasawneh that "the contribution of Islamic law was significant" (88), but even claims that "Islam's contributions go beyond these rules to cover other areas, such as diplomatic immunity, maritime law, asylum, interstate trade, laws of treaties, enemy territory and property, and laws of safe conduct” (88). But again - how far did that go, how if at all - did it influence Western mainstream international law, what do potential bridges look like and what are possible points of conflict? As Powell clearly and - given the increasing dissemination of Islamic legal thought through the increasing number and importance of regional organizations founded by ILS, as reflected in e.g. the Charter of Organization of Islamic Conference (OIC), OIC Cairo Declaration of Human Rights or Arab Charter on Human Rights - probably rightfully states that "the reach of Quran and sunna does not stop at ILS' borders" (154), there would have been the unconditional need for Powell to provide clear answers to the questions what this development means concretely for mainstream international law and non-ILS in international law - both from an Islamic legal theoretical perspective and a practical IR perspective.

In addition, Powell could have done her and her readers another favor by referring to a higher degree to existing IR concepts that could have helped her to deal with specific IR problems that also occur in the context of the Islamic law-international law connex. At one instance, Powell shows that Sharī'ah often was incompatible with international law. In this context, she presents a dilemma, namely, that on the one hand, Sharī'ah provides ILS' leaders with legitimacy which these not only need for their domestic political authority but which is also required for decision-making in the international realm. This dilemma is even aggravated by the fact that Muslim citizens of ILS countries expected Sharī'ah to play a role in domestic and international politics (155) as clearly demonstrated by the recent uprisings in ILS that regularly led to influx of Islamic ideas in state constitutions (156). But while Powell demands that this dilemma needed to be understood and taken into consideration by Western leaders (162), she does not show how to understand and deal with this dilemma. Here it would be possible and recommended to provide an explanation based on a concept such as the two-level-games approach by Robert Putnam. By training a political scientist, Powell is, as she reveals herself, interested in behavioral patterns, knowing that behavior reflects preferences. These patterns and their corresponding preferences take place within a context of domestic-international interaction. As Powell explicitly states that her "book also advances international relations [literature[s]]" (17), it comes with some surprise, that there is no explicit reference to relevant works from the field. It would have been more than interesting to take up this line of argument from IR scholarship that connects and explains the interaction between the national and international levels, beginning with Singer's discussion of the level of analysis to the just mentioned concept of two-level-games by Putnam. Answering these more fundamental answers mentioned before and adding, where suitable, existing explanatory models from IR and possibly other sciences would have done a great service to the highly interesting results from her empirical analysis concerning the various dispute settlement mechanisms preferred by ILS.

These results certainly are what Powell really was interested in. Here the reader can see the full strength of Powell's scholarship. While the first chapters rather appear as an unavoidable compulsory exercise, the three empirical chapters become what in sports would be the free section; the part of one's liking to promenade with. In the three chapters that comprise Powell's empirical analysis, she examines first ILS' dispute settlement behavior in territorial conflicts in the years between 1945 and 2012, second, the dealings between ILS 
and the ICJ and, third and fourth, the possible impact of the regional factor and the factor represented by the existence of seven different legal schools of thought in Islam. Her empirical analyses are straight forward. She uses two different models: a logit model and a negative binominal model to run her analyses with. For each of the empirical tests, she comes up with a number of factors to operationalize her variables. The selection of the respective variables appears very convincing even if the author could have provided a more extensive justification for her choice.

In her first empirical chapter, Powell tests two specific hypotheses. The first hypothesis

Islamic Law and International Law (H 5.1) states that "Islamic law states whose domestic laws embrace traditional Islamic law principles are more likely than other Islamic law states to resort to non-binding third-party methods in attempting to settle their territorial disputes," while the second hypothesis $(\mathrm{H}$ 5.2) states that "Islamic law states whose domestic laws incorporate secular/shared principles are more likely than other Islamic law states to resort to binding third-party methods in attempting to settle their territorial disputes." Her independent variables therefore are the domestic legal systems of the respective ILS which appear either in the form of embracing traditional Islamic law or secular/shared law. A legal system of the first kind was operationalized with the following factors: constitutional presence of Shari' ah/ Islam, of holy oaths, requirement of a Muslim head of state, supremacy of Sharī'ah within the legal system, Shari' ah-based education and the existence of customary law. The second type was operationalized by the following factors: constitutional existence of rule of law, a supreme court or high court, secular courts, women in judiciary, peaceful resolution of conflicts and education. As control variables, the strategic value (in the sense of the existence of military bases, shipping lanes in the disputed territory), the economic value (in the sense of natural resources ranging from oil to fishing grounds in the disputed territory) and ethnic value (in the sense of minorities beyond the border of a disputed territory), were used. Furthermore, Powell referred to other additional control variables, namely, capabilities (in the sense of the military capabilities of the states involved), joint democracy, past fight (in the sense of the existence of previous armed conflict in the existing issue during the previous 50 years), treaty commitments (in the sense of the number of peaceful settlement agreements) and time. The respective data were drawn from reliable data sets such as Multilateral Treaties of Pacific Settlement Data Set or the Correlates of War Data Set.

The tests of H 5.1, to which I will confine myself here, showed the following results: the constitutional requirement of a Muslim head of state correlated in a statistically significant way with a preference for negotiations or non-binding third-party venues. Also, Sharīah-based education which is deemed particularly important as it expresses state identity as it disseminates Islamic values into virtually the entire society of an ILS signaled a preference for negotiations or non-binding third-party venues. This, however, as Powell makes clear, did not mean a shying away from international justice as such, but preference for conciliation and mediation does not translate into support for international courts or arbitration tribunals (195). Rather, Islamic intermediaries such as the Arab League, the Islamic Conference Organization, the Gulf Cooperation Council and presidents/envoys from important states of the Islamic world, such as Egypt, Jordan or Saudi Arabia, are the means of choice for this type of ILS (196). One of the most surprising findings is the correlation of the Supremacy of Sharia and a support for international third-party binding venues, for which Powell delivers the respect for justice in Islamic law as probable explanation (196). The strict notion of pacta sunt servanda in Islamic law to which Powell alludes in this context could be regarded as another bridge between the systems as also in the Roman jus gentium, this principle played an important role binding not only non-Romans but the Roman Empire itself vis-à-vis the foreigners and thus may be seen as an embodiment of respect for justice in "Western" international law and Islamic law alike. This could also go well 
REPS

5,4

350

along with the finding of the constitutional existence of customary law in ILS where, if recognized, a strong correlation with the acceptance of third-party binding methods over nonbinding options was detected by Powell (197). The explanation here is that customs are important in the Islamic and the international law systems alike (198). Despite these interesting as important findings, some critical notes remain. For example, is respect for justice mentioned as a particularly Islamic feature. What about respect for justice in Western legal thought and whither the respective implications for the Islamic law-international law-nexus? Another aspect of second thought refers to Powell's argument concerning the different understandings of a constitutional statement that Shari' ah was above all. She states that for (often Western educated) drafters of constitutions and governmental elites, a constitutionally enshrined Sharí ah embodied "the good" also in the sense of good governance while in the eyes of the citizens, it might well be understood in the narrow sense of the state's commitment to Islamic criminal law. While this is an important statement, it does not become clear in which sense it should be understood here. Furthermore, it does not become evident, whether and when Sharī'ah is playing a rather instrumental role, a possibility also alluded to by the author, and what implication that would have.

The empirical test of the relationship between ILS and ICJ is also based on two hypothesis with the first one (H 6.1) stating that "Islamic law states whose domestic laws embrace traditional Shari' ah principles are less likely than other Islamic law states to recognize the jurisdiction of the International Court of Justice" and the second one (H 6.2) stating that "Islamic law states whose domestic laws incorporate secular/shared principles are more likely than other Islamic law states to recognize the jurisdiction of the International Court of Justice". The operationalization of the independent variables is identical as to the previous test. As control variables, capabilities, democracy, treaty commitments and time are used. As far as H 6.1 is concerned, the results show strong support by the Peaceful Resolution of Disputes variable in the context of compulsory jurisdiction; if embedded in an ILS' constitution, it drives ILS to ICJ and increases the likelihood of accepting compulsory jurisdiction. With respect to the Education in Constitution variable, a behavior less likely to sign the optional clause is associated. This is seemingly contradictory, yet the explanation provided by Powell appears convincing: it is coded yes if there is any type of education in the ILS' constitution. Thus, also non-secular types of education including even Shari' ah are included (227 f.), which might put somewhat in question the choice of this particular variable. This time, I also want to take a brief look on some of the important findings concerning $\mathrm{H}$ 6.2. Looking at the results, it becomes clear that if Islamic law however interpreted is embraced in the domestic law system of an ILS, then it is less likely that the ILS will support the ICJ (229). The same is true with respect to the variables Muslim Head of State and Sharia Education (229). Despite some statistical issues (numbers in parts of analysis not sufficient to estimate a Markov transitional logit model in some respects), the holy oath variable is positive (and statistically significant) to compulsory jurisdiction, and negative (and statistically significant) to the compromissory jurisdiction model (229). Concerning the variable Shari'ah in the constitution, there is a correlation with a lack of compatibility with international law. An important aspect here seems to be the different interpretation of different social groups and the political elite, which, however, would have been needed to be explained to a larger extent by the author. What becomes evident yet is that an accepting clause does not exclude other means of conflict resolution. In other words, as shown by Powell, the ICJ represents not more and not less than an additional option. What also becomes evident is again the strong meaning of the pacta sunt servanda component is Islamic law. This finding corresponds with the outcome of the variable Supremacy of Sharia. Thus, Powell's explanation is accordingly: possibly because of a strong pacta sunt servanda component in Islamic law, ILS' commitments to the ICJ are "more durable than those of common law or civil law states" (231). As far as the control variables are concerned, it can be seen that three out of the total of four exert significant influence on ILS' attitudes toward the ICJ, but 
only as far as compulsory jurisdiction is concerned (233). While the time variable unsurprisingly offers a (statistically significant) negative correlation with compulsory modes (233), the treaty membership variable clearly indicates as (statistically significant) positive correlation to this kind of conflict resolution modes, a fact that by Powell is interpreted as an expression of ILS' overall commitment to the international system (233).

The final set of empirical analysis concerns the Islamic schools of thought and the different regions where ILS are located. While on the one hand, according to Powell it "is clear that different regions have unique perspectives on international law and its institutions" (239 f.), on the other hand, no systematic studies of the views about international conflict resolution by the Islamic schools of jurisprudence exist. The questions of whether Islamic legal schools mattered in how ILS view international conflict management methods and if there were regional variations how ILS see these measures are regarded by Powell of particular importance as she expects to acquire information on ILS' preferences with respect to institutionalized global justice, moving beyond the current focus on the domestic system (240). At the same time, she makes clear that she saw no inherent reason why geographic regions or particular schools of legal thought should travel together with the position of the ILS on the secular law-Islamic law scale (240).

In the book, Powell gives a general introduction into the maddahib, mentioning e.g. the Amman Message which stated that there were currently four Sunni and two Shia legal schools that provided widely acknowledged, but often also widely diverging interpretations of Islamic law (241 ff.). In her own understanding of Islamic schools of law, the author's work comprises seven such schools, adding to Hanafi, Hanbali, Maliki and Shafii on the Sunni side and Jafari and Zaidi on the Shia side and the Ibadi school which predates Sunni and Shia jurisprudence but has limited reach in either of the main Islamic manifestations. It is positive to see that Powell herself recognizes the limitations of classifying an ILS as being represented by or representative of a particular maddhab, let alone in an official way. The author rather attempts to show whether a specific school is prevalent in a particular ILS; counted as this would be the maddhab that lays claim to the largest portion of the respective ILS' population (242). What, apart from the already mentioned, adds to the problematic side is the relative weak role of scholars (ulama) in official state frameworks, as well as the issue of forum shopping which might lead to a selective choice of arguments of different maddahib in the politico-legal practice ( $245 \mathrm{ff}$.). With respect to the schools, Powell presents two hypotheses (H 7.1 and H 7.2), while concerning the regions aspect, four additional hypotheses (H 7.3-H 7.6) are presented.

Without going into the details, the results show that the kind of prevailing maddhab neither has any bearing on the choice of the settlement mechanism in the context of territorial disputes nor when it comes to accepting ICJ jurisdiction. Analyzing the regional factor, Powell presents some interesting insights (250 ff.): the Middle East region shows a very strong influence of Arab and Beduin traditions with its skeptical implications vis-à-vis formalized modes of dispute settlement and formal institutions. Africa appears to show an increased acceptance of these mechanisms and institutions because of recent positive experiences in the context of a strengthened regionalism after long years of great difficulties and extensive conflict. Asia and Oceania as a distinct region show a rather high degree of indistinctness as far as domestic legal systems are concerned resulting in a somewhat open attitude to international conflict resolution. A high degree of diversity when it comes to domestic legal systems of the ILS in this particular region ranging from Confucianism to Western forms is correlating to a fairly unbiased attitude vis-à-vis the methods and institutions in question. Summing up the respective findings, it can be said that ILS in the Middle East is more inclined to non-binding third-party measures and less likely to accept jurisdiction of the ICJ as compared to ILS from other regions. At the same time, ILS located
Islamic Law and International Law

351 
REPS

5,4

in Africa are more inclined to binding third-party measures, even if this finding is only partly supported by empirical data: While it is true when compared to the ILS in the Middle East, the picture turns out to be significantly less clear in the comparison to ILS in the Asian/Oceanic region. Strong support can be observed, however, for the hypothesis that ILS in Africa are more likely to accept jurisdiction of the ICJ. All in all, it can be stated that different from the maddahib, the region at least has some bearing.

In the final part of this review, a critical eye shall be set on Powell's dealings with the dispute settlement arguments in some more detail. Her main arguments to be tested are that ILS whose domestic laws embrace traditional Islamic law are more likely than other ILS to resort to non-binding third-party methods in attempting to settle their territorial disputes and ILS whose domestic laws incorporate secular/shared principles are more likely than other ILS to resort to binding third-party methods in attempting to settle their territorial disputes. In this context, Powell sees an important "disconnect between the way that the Western and Islamic milieus approach conflict management" (196). As far as international law is concerned, peaceful dispute settlement is regarded as "bedrock of international law" (128). This can take the form of bilateral negotiations without an intermediary which often are prerequisite to adjudication (129). In this context, a striking feature of this type of settlement approach is that serious disputes might cause parties to break diplomatic relations (130). Other forms comprise conciliation in the sense of institutionalized negotiation where an intermediary sets the framework. This does not lead to a binding decision, but chances are good that this type of approach contributes to peaceful conflict settlement (130). Arbitration and adjudication eventually are binding third-party mechanism according to international law. They comprise the agreement in advance to accept and follow the attained outcome, which is an award in the case of arbitration, and a judgment in the case of adjudication (131).

While perceived as legal standard in international law and also in countries from a Western background, in the eyes of Powell, dedicatedly Western legal design causes some significant problems for ILS. First and foremost, so the argument of Powell, it was the uncertainty of outcome of such a mechanism which was because of possible variations in the interpretation of applicable legal norms $(133,137)$, a problem that is even made worse by very character of international law with its many loopholes and areas hardly even covered by substantial norms. This shortcoming increased the extension of variety when it comes to legal interpretation even more as judges, for example, tried to take into account the different understandings of law of the rival parties, and thus could then offer only particular interpretations or had to interpret by referring to various and possibly differing domestic analogies. Furthermore, judges had very different legal backgrounds and were brought up in very different legal traditions and understandings of law (134 ff). All these aspects, Powell states, for states meant giving up control over a contention which they tried to avoid as good as possible (134). Particularly tough for ILS was in addition the fact that Islamic influences were simply non-existent in arbitration and adjudication (137).

While it is very interesting for the reader to deal with these doubtlessly real and serious difficulties, (s)he again is missing some further explanations as well as attempts to differentiate somewhat more. On the one hand, the problem is presented as a universal one as it is argued that judges come from all over the world representing a whole variety of legal traditions within international institutions. This, however, would mean a resulting insecurity for all states that address these institutions for litigation as the judges refer to very different domestic traditions in interpreting international law. Again, Powell presents mainstream international law as a translation of "the" (unitarian) Western law only on the higher level. But this lack of differentiation does not correspond entirely with the vast 
differences legal systems and traditions show within the Western realm (however defined). This is not to say that states lacking completely a history of any of those legal concepts and traditions which predominantly can be found in the context of Western states, might find it even harder or less calculable when it comes to going into dispute settlement mechanism of respective international law bodies. But paying tribute to the real complexity would have required a much more differentiated way of dealing with this issue particularly as it is one of the cornerstones of Powell's argument. For example, even if she writes that the majority of the judges in international dispute settlement bodies are Western trained, the question arises Islamic Law and International Law whether this really rules out the possibility that they still have a very good understanding for the political, social and even legal realities of their possibly non-Western countries of origin, including ILS. At least it should be discussed whether this might then rather be an advantage than a disadvantage for the ILS and why this is the case or not.

Furthermore, it would have been necessary to show in greater precision and to a higher degree of differentiation which domestic legal systems and legal traditions are represented in the various international institutions of peaceful dispute settlement the author alludes to, in particular, the ICJ. For this, it would have been necessary to come up with impeccable criteria on how to measure exactly the influence of a domestic legal system and a particular tradition on the decision-making of the judges. In addition, the ratio of the judges with different legal backgrounds and based on this what difference it made concretely should have been shown and discussed. It is unfortunate, that the Latin American, African or Asian legal systems (beyond ILS) are not mentioned explicitly. Are they all counted as Western? And that, as mentioned before, the author does not differentiate well-enough within "the" Western law traditions. What this comes down to, if reading at extreme face-value, is basically a dualism of Western law (comprising British, Continental European, US, Northand Latin American, African and Asian legal traditions minus ILS within these regions) vs ILS law (differentiated according to certain criteria ranging from more "liberal" versions in Malaysia or Indonesia to the "stricter" varieties in Saudi Arabia or Iran). This is not exactly helpful, neither for the reader nor for the study itself. Of course, it is undisputed, that for the purpose of an empirical study, a certain degree of simplification of the complexities of reality is unavoidable. It must not become too strong a distortion of reality, however. In this case, some less rigid reduction certainly would have added to a fair argument.

Notwithstanding these thoughts, the author convincingly argues that the Islamic law tradition encompasses a distinctively less confrontational mode of conflict-resolution than it can be found at least in some parts in mainstream international law $(89,126)$. Powell shows that within the Islamic context, the confrontation within a court de-facto made enemies out of the parties, while conflict resolution beyond the court kept the way open in a non-enemy status (147). The particular advantage of informal out of court solutions were that they integrated the conflict parties in a step-by-step process, which eventually made the whole process better calculable with the outcome being by far less surprising as in the case of formalized arbitration in the international law context (149). The respective sources of legitimation were also well known in the Islamic tradition, namely, personal traits, authority and the prestige of the arbitrator. This familiar format tends to be suitable in making non-binding third-party methods particularly attractive to ILS (150).

An important and particular feature in the Islamic legal tradition according to Powell was justice (129). Therefore, as argued by Powell, it was also the administration of justice that "lies at the heart of traditional Islamic court procedure" (140), where the focus was on "ethics, culture, morals, and societal harmony" (140). This particular set-up also made Islamic law the least formal and highly flexible (140). While it does not sound too convincing that attaining justice is a feature limited to the Islamic legal tradition explicitly (and thus excluding it from [however defined] 
REPS

5,4

Western legal traditions), there might be some more truth in what Powell states with respect to European and American litigation models which she depicts as "inherently based on a winner/ loser dichotomy as well as legalistic and rational argumentation" while the Islamic concept of settlement "relies on myriad extralegal values such as communal benefits, societal needs, and religion" (142). But even this contrast is by far too stark as it not only denies the already mentioned strive for justice that is of course part of Western legal (as well as political and social) philosophy, but also does not take into consideration that judgments while making an individual decision for each case do by far not ignore extra-case factors, aspects and implications. The problem of constructing too rigid a divergence between Islamic and Western cultures of law can be seen when it comes to alternative dispute resolution. Powell states that in several ILS "mediation between disputants is encouraged officially by the courts or constitutes a prerequisite for judicial proceedings" (145). This, however, is also current practice in many Western legal systems. But also communal benefits for example play a role. For example, the social obligation of property is a central feature of the constitutional understanding and thus needs to be accounted for in court rulings. Another important feature that can be found in many "Western" states is the so-called ombudsperson whose tasks roughly spoken traditionally comprise the representation of the interests of the public by investigating and addressing complaints of maladministration or a violation of rights. The typical duties of an ombudsman are to investigate complaints and attempt to resolve them, usually through recommendations (binding or not) or mediation. As far as the mandate is concerned, most ombudspersons have a wide mandate to deal with the entire public sector and sometimes and as a matter of fact to an increasing degree, also with elements of the private sector (e.g. contracted service providers).

Where does this critique finally lead to after all that has been discussed? Summarizing it can be said that Powell doubtlessly addressed a topic of high relevance for the audiences for which she wrote the book. Thus, the ideas of her book have the potential to generate an impact in the academic world as well as in the practice of international law and international relations alike, particularly when it comes to conflicts with an involvement of ILS. The central idea of the book is brilliant and the empirical chapters which test her hypotheses are by and large convincing. Representing the center piece of Powell's analysis, this is of crucial importance. Every centerpiece, however, can only shine unstintingly if also its framework is of respectively high quality. Without an adequate contextualization, even excellent empirical data cannot be valued to their fullest as only a high-quality contextualization enables to really understand the meaning of the results. For Powell's book, it might be said that the contextualization is less convincing than her core part itself. As a whole, she undertakes a highly interesting and important attempt to answer a research question of both academic and practical use. It is indeed crucial to learn more about why ILS prefer a particular type of crisis solution mechanism and what can we imply from this particularly for the practice of international relations including international law. It is an excellent endeavor with a highly convincing methodological design. Applying a mixed-method approach that combines rigorous quantitative tools with extensive qualitative research including in-depth interviews with a large number of crucial figures in the field of her research tremendously adds to the quality.

Also, the findings she presents are convincing and offer excellent insights. It is important to learn that both Islamic law and international law are dynamic and evolving legal traditions and also that both systems have transformative potential that, if realized, can bring about a more peaceful world (24). Equally important is the insight that the Islamic legal system does not operate in a binary manner in the sense of either Islamic or nonIslamic (199). This fact is convincingly shown statistically. Last but not least, the finding that "[n]on-legalized venues such as negotiations, conciliation, or mediation allow Islamic 
law states to 'customize' the mechanism inherent to settlement venues to reflect their own preferences toward the nature of social interaction" (196) is of great value. The layout of the book is good, a number of informative tables help to present the statistical results. Nevertheless, the variables could also have been delivered in a somewhat more comprehensive way, for example in a brief table. But this is no more than minor cosmetics.

What weighs somewhat more heavily is the fact that particularly in the first chapters of the book (in particular in chapter 1), Powell tends to be very repetitive, mentioning on several occasions what she wants to get down to in her book. At the same time, the various ways of and International Law showing this at some occasions even is slightly puzzling. There are so many effects and minor outcomes and implications mentioned or alluded to that the reader once and again has to look for the guiding thread to be back on the main track of Powell's argument. While not agreeable, it does by far not count as heavily as the fact that on too many occasions undue simplifications particularly when it comes to present the Western tradition - distort the picture. This is the more regrettable as Powell tries purposefully to avoid the problematique in the context of the Islamic tradition. Why the author chose to pursue this strategy is not entirely clear. While a strong antagonism between the systems might reflect a widely held perception and presenting the avenues to bridge it, which her theory helps find, might show a particular success of her effort. At the same time, a more differentiated discussion, as mentioned before, would in no ways undermine her main argument, but even underline it at least in some respects. This type of simplification also cannot be justified on grounds of shortness as Powell wrote a book, not an article. Apropos book, even if paying tribute to the fact that her work expressively is not a textbook, the foundational or contextual chapters should still be more substantial, systematic and comprehensive than in a mere essay where cursory dealings with important issues are more acceptable.

All in all, Emilia Justyna Powell's Islamic Law and International Law: Peaceful Resolution of Disputes is definitely worth reading, in particular when it comes to the empirical chapters and her core assumptions and findings. It shall neither be a textbook nor a history and as shown, the foundational chapters dealing with international law, Islamic law are not entirely inviting to widen or deepen one's knowledge on these issues. They could have been done better, more informative, more differentiated and therefore also much more valuable for Powell's argument and way beyond. This would also have served the possibly most important aim of her book: to be a contribution to a more justifiable and legitimate global order (6). Let us wish that despite the mentioned shortcomings, the truly important and valuable findings of Islamic Law and International Law: Peaceful Resolution of Disputes will help reach this goal. The author, the book and the world deserve it.

\section{Corresponding author}

Alexander Niedermeier can be contacted at: Alexander.niedermeier@googlemail.com

For instructions on how to order reprints of this article, please visit our website:

www.emeraldgrouppublishing.com/licensing/reprints.htm

Or contact us for further details: permissions@emeraldinsight.com 